\title{
The Effect of Emotional Professional Ethics and Intelligence on Auditor Decision Making (Case Study at Public Accounting Firm in South Jakarta)
}

\author{
Marsyaf \\ Economics and business Faculty, Universitas Mercu Buana Jakarta
}

\begin{abstract}
This research is know the influence of Professional Ethics and Emotional Intelligence for Auditor Decision Making. The object is the auditor working on Public Accounting Firm or KAP located in South Jakarta. This research is conducted on 100 respondents by using quantitative descriptive approach. Therefore, the data used is statistical analysis in the form of multiple linear regression test. The results of this study indicate that simultaneously variable of Professional Ethics and Emotional Intelligence to Auditor Decision Making at KAP in South Jakarta. This is evidenced from the results of simultaneous test ( $F$ test) and partial test results ( $t$ test) also showed significant value of two variables that support the hypothesis that is Profession Ethics and Emotional Intelligence. Therefore the test results of this study states that there is a simultaneous influence between the variables of Professional Ethics and Emotional Intelligence on Auditor Decision Making in KAP in South Jakarta.
\end{abstract}

Keywords: Professional Ethics, Emotional Intelligence, Auditor Decision Making

DOI: $10.7176 / \mathrm{EJBM} / 11-24-04$

Publication date: August $31^{\text {st }} 2019$

\section{INTRODUCTION}

The main benefits of KAP services is providing accurate and reliable information for decision making. Financial statements that have been audited by KAP, the fairness is more reliable than financial statements that are not audited. Therefore, an independent and objective professional service is needed (i.e. public accountants) to assess the fairness of the financial statements presented by management. The term professional means the responsibility to behave more than just fulfilling the responsibilities assigned it.

The professional requirements are demanded by independent auditors are people who have education and experience practicing as independent auditors. The term Independent means that in every decision making it is in accordance with the policies and procedures established so that the public accounting firm gets a proper belief, where an auditor is not influenced by any party. Decisions taken are not based on the interests of the client, personal, or other parties, but based on the facts and evidence that were successfully collected during the assignment. Meanwhile, the objective term is a quality or value for the services provided by members. The principle of objectivity requires members to be fair, impartial, intellectual honest, not prejudiced or biased, and free from conflicts of interest or under the influence of other parties.

An auditor in making definite decisions uses more than one rational consideration, which is based on the implementation of applicable ethics that he understands and makes a fair decision. In addition, education and experience can also improve their competence in decision making. But in dealing with other parties (audite) an auditor in addition to having intellectual abilities must also have organizational skills, interpersonal and attitude in a career in an ever-changing environment.

According to Goleman (2001) in Henda Sandika Kusuma (2011) dividing emotional intelligence can be affected the success in working into 5 main parts, namely self-control, self-regulation, motivation, empathy and social skills. A person with well-developed emotional intelligence is more likely to succeed in his life because he is able to master thinking habits that drive productivity. For auditors, it is important to convince clients and users of financial statements of audit quality and other services. Therefore, there is a strong push for auditors to act with high professionalism. The trust of the government and society towards the business world or services provided by business executors, especially auditors, demands an understanding of the professional ethics concerned.

Based on the background above, the researchers want to conduct research with the title "THE EFFECT OF PROFESSIONAL ETHICS AND EMOTIONAL INTELLIGENCE ON AUDITOR DECISION MAKING". (Case Study at the Public Accountant Office in South Jakarta)

\section{STUDY OF LITERATURE, FRAMEWORK FOR THINKING AND HYPOTHESIS}

Agency Theory (Agency Theory)

Jensen and Meckling (1976) describe this agency theory to help the auditor understand the conflict of interest that arises between the principal and the agent. Principals as investors work together and sign work contracts 
with agents or company management to investigate their finances. With the existence of auditors who have integrity and independence, it is expected that there will be no more fraud in the financial statements made by management. So that it will produce relevant information that is useful for investors and creditors in making rational decisions for investment.

Behavior Theory

Krech and Krutchfield (1983) in Kusuma (2011), said that attitude is a state in human beings that moves to act, accompanies humans with certain feelings in response to objects formed on the basis of experiences. Attitudes on a person will be a pattern or color to the behavior of the person.

Auditing.

Meutia (2004) in Christiani and Nugrahanti (2014) defines audit as a process to reduce the inconsistency of information that exists between managers and shareholders by using outsiders to provide endorsement of financial statements.

From the definition, it can be concluded that the audit is a service provided by the auditor in examining and evaluating the financial statements presented by the company. This examination is not intended to find fault or find fraud even though it is possible to find errors or fraud in its implementation.

Ethics

Ethics is a scientific discipline concerning the values associated with individual behavior, relating to the truth and error of certain actions, as well as the good and bad of some of the motives that lead to these actions. Ethics is used when an individual needs to make decisions from various alternatives related to moral principles.

Emotional Intelligence

According to Wibowo (2002) in Henda Sandika Kusuma (2011) emotional intelligence is intelligence to use emotions according to desire, the ability to control emotions so that they have a positive impact. Emotional intelligence can help build relationships towards happiness and well-being.

\section{Auditor Decision Making}

According to Nuryanto (2001) in Kusuma (2011), decision (decision) means choice (choice), which is the choice of two or more possibilities. While according to Morgan and Cerullo quoted by Nuryanto (2001) in Kusuma (2011), decisions are: "A conclusion reached after consideration, which occurs after one possibility is chosen, while the other is ruled out"From the definition, it is clear that before this decision is established, thorough consideration is needed of the possible consequences that may arise, because maybe the decision taken only satisfies one group or only some people. But if we pay attention to the consequences of a decision, it can almost be said that there will not be a single decision that will please everyone ...

Logical Framework

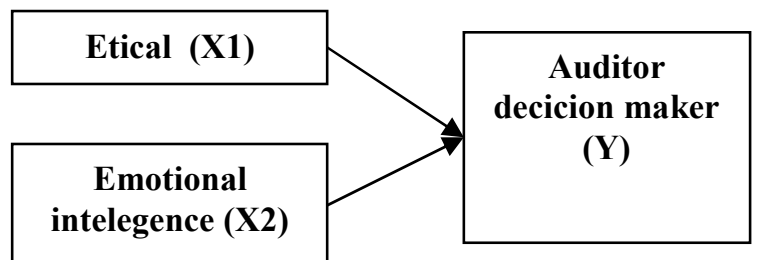

Hypothesis

1. Professional Ethics has a positive effect on Auditor Decision Making

The results of the research of Adelia Lukyta Arumsari and I Ketut Budiartha (2016) are professional ethics influencing auditor decision making. These results illustrate that in general most respondents (auditors) view the importance of professional ethics principles in auditor decision making.

This result is in line with Mardiah's research, Rizal Effendi and Oloan Siagian (2016) which states that professional ethics have a positive and significant effect on auditor decision making.

H1: Professional ethics has a positive effect on decision making.

2. Emotional Intelligence has a positive effect on Auditor Decision Making

The results of the Kusuma (2011) study are emotional intelligence influencing auditor decision making. These results illustrate that the higher the auditor's emotional intelligence will increasingly influence the auditor's decision making.

H2: Emotional intelligence has a positive effect on auditor decision making.

\section{RESEARCH METHODOLOGY}

The research method carried out in this study was a causal study. Causal Study is research that aims to describe the causes of one or more problems (Now \& Bougie, 2013). In this study, a causal study is used to examine the effect of information technology sophistication, management participation, and accounting manager knowledge 
on the effectiveness of accounting information systems. The population in this study is the auditor working at the Public Accounting Office (KAP) in the South Jakarta area. 1358 auditors. While the number of KAP itself varies depending on the random sample to be taken.

The dependent variable in this study is auditor decision making. According to Esa (2014) decision making is taking alternative behavior from two or more alternatives (leadership actions to solve the problems faced in the organization he leads by choosing one of the possible alternatives).

The independent variable in this study is Professional Ethics. According to Rahayu and Suhayati (2013) professional ethics is a guideline that must be applied by an auditor in carrying out his activities. Public accountants are professions that have the predicate of their expertise.

Emotional Intelligence.

Salovey and Mayer (2005) define emotional intelligence or what is often called EQ as, "a subset of social intelligence that involves the ability to monitor social feelings that involve abilities in others, sort through everything and use this information to guide thoughts and actions." .

Operational Variable

\begin{tabular}{|l|l|l|l|}
\hline Variable & Research Variable & Indicator & Scale \\
\hline Independent & Ethical profession & $\begin{array}{l}\text { Responsibility } \\
\text { Integrity } \\
\text { Objective } \\
\text { Independent } \\
\text { Double act } \\
\text { Client screat }\end{array}$ & Ordinal \\
& & $\begin{array}{l}\text { Awareness } \\
\text { Control } \\
\text { Motivation } \\
\text { Empathy }\end{array}$ & \\
\hline Independent & Emotional intelligence & Ordinal \\
& & $\begin{array}{l}\text { Accountancy standard } \\
\text { Accountancy action } \\
\text { No evidence }\end{array}$ & Empirical \\
\hline
\end{tabular}

Sample Selection Criteria

Total population in this study is all auditors working in the Public Accounting Office in South Jakarta registered on IAPI as many as 1358 auditors. In this study the authors narrowed the population,by using the number of auditors 100 people by calculating the sample size carried out using Slovin techniques according to Sugiyono (2011: 87).

\section{Discussion Tabel 1. Statistic}

\begin{tabular}{|l|r|r|r|r|r|}
\multicolumn{7}{|c|}{ Descriptive Statistics } \\
\hline & \multicolumn{1}{|c|}{ N } & Minimum & Maximum & \multicolumn{1}{c|}{ Mean } & Std. Deviation \\
\hline EP & 100 & 17.00 & 30.00 & 23.8500 & 3.03640 \\
KE & 100 & 15.00 & 25.00 & 19.6200 & 2.39013 \\
PKA & 100 & 14.00 & 23.00 & 17.9300 & 2.47106 \\
Valid N (listwise) & 100 & & & & \\
\hline
\end{tabular}

(Source : SPSS 23, 2017)

From the table above it can be describe:

$1 . \mathrm{N}=100$, meaning that the amount of data obtained in this study is 100 data consisting of 9 samples of public accounting firms or KAP in the South Jakarta region in 2017.

2. EP has an average value or mean of 23.8500, then EP has the lowest value of 17.00 and the highest value of 30.00 with a standard deviation of 3.03640. This 3.03640 standard deviation value shows lower than the average value or mean of 23.8500 , so that it can be interpreted if the data distribution is evenly distributed.

3. KE has an average value or mean of 19.6200 , then KE has the lowest value of 15.00 and has the highest value of 25.00 with a standard deviation of 2.39013. The standard deviation value of 2.39013 shows lower than the average value or mean of 19.6200 , so that it can be interpreted if the spread of data is evenly distributed.

4. PKA has an average value or mean of 17.9300, then PKA has the lowest value of 14.00 and has the highest value of 23.00 with a standard deviation of 2.47106. This standard deviation value of 2.47106 shows lower than the average value or mean of 17.9300 , so that it can be interpreted if the spread of data is evenly distributed. 
Table 2. normality test

One-Sample Kolmogorov-Smirnov Test

\begin{tabular}{|ll|r|}
\hline & & $\begin{array}{r}\text { Unstandardiz } \\
\text { ed Residual }\end{array}$ \\
\hline $\mathrm{N}$ & & 100 \\
Normal Parameters & Mean & .0000000 \\
Most Extreme Differences & Std. Deviation & 2.27822952 \\
& Absolute & .056 \\
& Positive & .056 \\
Test Statistic & Negative & -.052 \\
Asymp. Sig. (2-tailed) & & .056 \\
\hline
\end{tabular}
a. Test distribution is Normal.
b. Calculated from data.
c. Lilliefors Significance Correction.
d. This is a lower bound of the true significance.

(Source : SPSS 23, 2017)

Based on the table above, it is known that the kolmogorov smirnov value is 0.56 and is significant at 0.20 until it can be concluded that the data used in this study are normally distributed due to the value of $0.20>$ than 0.05 .

Table 3. Multikolinerity test

Coefíients $^{a}$

\begin{tabular}{|c|c|c|c|c|c|c|c|c|}
\hline \multirow[b]{2}{*}{ Mads } & & \multicolumn{2}{|c|}{ Unstandardized Coefficients } & \multirow{2}{*}{$\begin{array}{c}\begin{array}{c}\text { Standardized } \\
\text { Coefficients }\end{array} \\
\text { Beta } \\
\end{array}$} & \multirow[b]{2}{*}{$t$} & \multirow[b]{2}{*}{ Sig. } & \multicolumn{2}{|c|}{ Collinearity Statistics } \\
\hline & & $B$ & Std. Error & & & & Toterance & VIE \\
\hline \multirow[t]{3}{*}{1} & (Constant) & 9.134 & 2.141 & & 4.267 & .000 & & \\
\hline & EP & .182 & .090 & .223 & 2.029 & .045 & .723 & 1.384 \\
\hline & $\mathrm{KE}$ & .227 & .114 & .220 & 1.997 & .049 & .723 & 1.384 \\
\hline
\end{tabular}

(Source : Data SPSS 23, 2017)

Based on the table above shows that there is no symptom of multicollinearity between independent variables which is indicated by the tolerance value of each variable greater than 0.10 and the Variance Inflation Factor (VIF) value is less than 10 . So it can be concluded that there is no multicollinearity between the independent variables in the model regression.

Table 4. Autokoleracy test

Model Summary

\begin{tabular}{|l|l|l|r|r|r|}
\hline Model & R & R Square & $\begin{array}{c}\text { Adjusted R } \\
\text { Square }\end{array}$ & $\begin{array}{c}\text { Std. Error of } \\
\text { the Estimate }\end{array}$ & $\begin{array}{c}\text { Durbin- } \\
\text { Watson }\end{array}$ \\
\hline 1 & $.387^{\mathbf{a}}$ & .150 & .132 & 2.30160 & 1.982 \\
\hline
\end{tabular}

a. Predictors: (Constant), KE, EP

b. Dependent Variable: PKA

(Sources : Data SPSS 23, 2017)

From the above testing model, it can be seen that the Durbin-Watson value (d) from the autocorrelation test results is 1.982 . Where the du value is $-2<1.982<2$ so it can be concluded that there is no positive or negative autocorrelation. 
Picture 1. Heteroskedastisitas

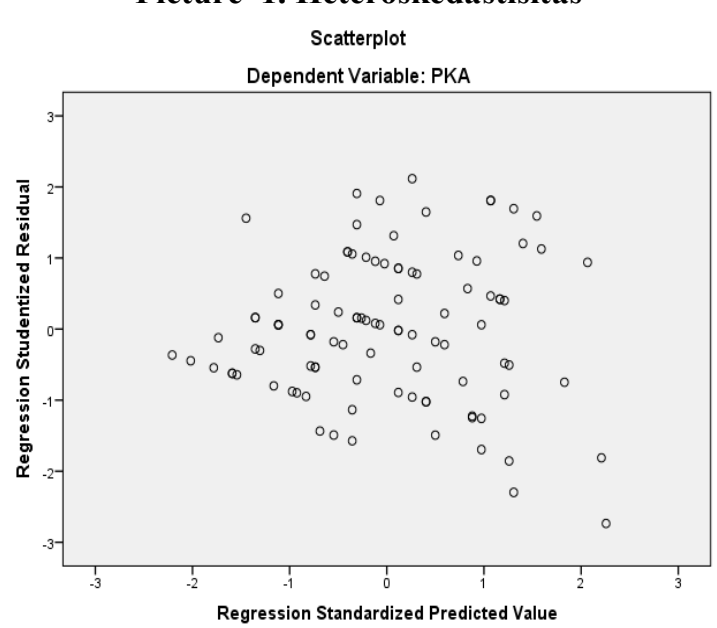

(Sources : SPSS 23, 2017)

From the scatterplots graph shows that the points spread randomly and spread both above and below the number 0 on the $\mathrm{Y}$ axis. It can be concluded that there is no heteroscedasticity in the regression model, so that a decent regression model is used to predict auditor decision making (PKA) based on input independent variables professional ethics (EP) and emotional intelligence (KE).

Table 5. coeficient Determination $\left(\mathbf{R}^{2}\right)$

Model Summary

\begin{tabular}{|l|l|r|r|r|}
\hline Model & R & R Square & $\begin{array}{c}\text { Adjusted R } \\
\text { Square }\end{array}$ & $\begin{array}{c}\text { Std. Error of } \\
\text { the Estimate }\end{array}$ \\
\hline 1 & $.387^{\mathrm{a}}$ & .150 & .132 & 2.30160 \\
\hline
\end{tabular}

a. Predictors: (Constant), EP1, KE1

b. Dependent Variable: ABSUT

From the results of these tests it can be seen that the adjusted R2 value is obtained at 0.505 . This means that $50.5 \%$ of the variation in company performance can be explained by variations of the five independent variables, while the other $49.5 \%$ can be explained by other variables.

Table 6. simulant Significancy Simultan ( F test statistic )

\begin{tabular}{|c|c|c|c|c|c|c|}
\hline \multicolumn{7}{|c|}{ ANOVA $^{\mathrm{a}}$} \\
\hline & & $\begin{array}{l}\text { Sum of } \\
\text { Squares }\end{array}$ & df & Mean Square & $\mathrm{F}$ & Sig. \\
\hline \multirow[t]{3}{*}{1} & Regression & 90.667 & 2 & 45.334 & 8.558 & $.000^{6}$ \\
\hline & Residual & 513.843 & 97 & 5.297 & & \\
\hline & Total & 604.510 & 99 & & & \\
\hline
\end{tabular}

Based on the table above it can be seen that the results of the calculation of the F statistic test are 8.558 with a probability of 0,000 . Because probabilities are smaller than 0.05 which means simultaneously or simultaneously all independent variables of professional ethics (EP) and emotional intelligence (KE) jointly influence the auditor's decision making (PKA).

Table 7. significant test ( $t$ test)

Coefficients $^{\mathrm{a}}$

\begin{tabular}{|c|c|c|c|c|c|c|}
\hline \multirow{2}{*}{\multicolumn{2}{|c|}{ Model }} & \multicolumn{2}{|c|}{ Unstandardized Coefficients } & \multirow{2}{*}{$\begin{array}{c}\begin{array}{c}\text { Standardized } \\
\text { Coefficients }\end{array} \\
\text { Beta } \\
\end{array}$} & \multirow[b]{2}{*}{$t$} & \multirow[b]{2}{*}{ Sig. } \\
\hline & & B & Std. Error & & & \\
\hline \multirow[t]{3}{*}{1} & (Constant) & 9.134 & 2.141 & & 4.267 & .000 \\
\hline & EP & .182 & .090 & .223 & 2.029 & .045 \\
\hline & KE & .227 & .114 & .220 & 1.997 & .049 \\
\hline
\end{tabular}

a. Dependent Variable: PKA

(Sumber : Data diolah melalui SPSS 20, 2017)

Based on the results of the statistical test $t$ can be seen between each independent variable on the dependent variable which can be explained as follows:

1. Professional Ethics (EP) has a value of $t$ count of 2.029 with a significance level of 0.045 , which means less 
than 0.05. This shows that professional ethics (EP) has a positive and significant influence on auditor decision making (PKA) so Hypothesis 1 (H1) is accepted.

2. Emotional Intelligence (KE) has a value of t count of 1.997 with a significance level of 0.049 which means smaller than 0.05. This shows that emotional intelligence has a positive and significant influence on auditor decision making (PKA), so Hypothesis $2\left(\mathrm{H}^{2}\right)$ is accepted.

\section{CONCLUSION}

Based on the results of testing and data analysis of the discussions that have been carried out previously, the conclusions obtained are as follows:

1. Professional Ethics (X1) has a positive and significant effect on Auditor Decision Making, this shows that an auditor who is able to maintain integrity, objectivity, competence and prudence in a professional manner, confidentiality and professional conduct well tend to have an impact on decision making the better. Everyone will face different conditions between theory and field practice. In this situation, an individual is likely to be faced with a conflict of interest, where the auditor is sometimes faced with difficult choices that can interfere with his integrity as an auditor. In this condition, the auditor needs to explicitly use his authority and stick to his professional code of ethics in resolving the issue of conflict of interest.

2. Emotional Intelligence (X2) has a positive and significant effect on Auditor Decision Making, this shows that an auditor who has the ability to recognize one's own feelings and other people's feelings, motivate themselves, and manage emotions well in themselves and in relationships with other people can influence good success in decision making. Emotional intelligence uses emotions according to desire, the ability to control emotions so that they have a positive impact. Emotional intelligence can help build relationships towards happiness and wellbeing

\section{Suggestion}

Based on the results of the research that has been done, the following suggestions are given:

1. For KAP

To improve the work performance of better auditors, an increase in the number of trainings is needed, as well as an opportunity for auditors, especially junior auditors to take courses or improve professional education so that auditors can better maintain their integrity and can carry out work in accordance with professional ethics and emotional intelligence.

2. For further researchers

It is expected to be able to use or add other research variables that are not used in this study, because this research only uses 2 (two) independent variables namely professional ethics and emotional intelligence. And it is hoped that further research will increase the number of respondents and expand the sampling location so that it can produce better results.

\section{References}

Anis Choiriah. (2013)."Pengaruh Kecerdasan Emosional, Kecerdasan Intelektual, Kecerdasan Spiritual, dan Etika Profesi Terhadap Kinerja Auditor Dalam Kantor Akuntan Publik (Studi Empiris Pada Auditor Dalam Kantor Akuntan Publik di Kota Padang dan Pekanbaru)". Program Studi Akuntansi. Fakultas Ekonomi. Universitas Negeri Padang..

Apriyanti. (2014).Pengaruh Kecerdasan Emosional, Kecerdasan Spiritual, dan Perilaku Etis Terhadap Kinerja Auditor.E-Journal S1 AK, Universitas Riau Jurusan Akuntansi Program S1 (Vol:1 No:2 Tahun 2014).(Studi Empiris pada BPK-RI dan BPKP Perwakilan Provinsi Riau)

Auliyah Mutia. (2015). "Pengaruh Pelaksanaan Etika Profesi Terhadap Pengambilan Keputusan Akuntan Publik (Auditor). Fakultas Universitas Islam Indonesia

Badjuri Achmat. (2011). Faktor-Faktor yang Berpengaruh Terhadap Kualitas Audit Auditor Independen. Program Studi Akuntansi Universitas Stikubank Semarang.

Boyton, Johson, dan Kell. 2003. Modern Auditing. Jakarta: Erlangga.

Budi, Sasongko. 2004. Internal Auditor dan Dilema Etika. Diakses dari http://www.theAkuntan.com pada tanggal 18 Desember 2017.

Candra Kurniawan. 2016. Pengaruh Etika Profesi Kecerdasan Intelektual dan Kecerdasan Emosional Terhadap Pengambilan Keputusan Auditor. Program Studi Akuntansi Universitas Mercu Buana.

Endang. Tanpa Tahun. Pengaruh Motivasi Kerja dan Etika Profesi Terhadap Pengambilan Keputusan Auditor. Jurnal Riset Akuntansi Indonesia. Hlm 10 -13.

Farah Zakiah. (2013). "Pengaruh Kecerdasan Intelektual, Kecerdasan Emosional, dan Kecerdasan Spiritual Terhadap Pemahaman Akuntansi (Studi Empiris Mahasiswa Jurusan Akuntansi Angkatan Tahun 2009 di Universitas Jember)". Jurusan Akuntansi Fakultas Ekonomi Universitas Jember.

Ford, Robert C and W.D, Richardson. 1994. Ethical Decision Making: Accounting and Business Reseach. Vol. 
13. Hlm 205 - 221.

Hayes, Rick. 2017. Prinsip-Prinsip Pengauditan. Edisi Ketiga. Salemba Empat: Jakarta

Henda Sandika Kusuma. (2011). "Pengaruh Pelaksanaan Etika Profesi dan Kecerdasan Emosional Terhadap Pengambilan Keputusan Bagi Auditor (Studi Empiris Pada Kantor Akuntan Publik dan Badan Pemeriksa Keuangan di Semarang)". Jurusan Akuntansi Fakultas Ekonomi Universitas Diponegoro.

http://iapi.or.id/Iapi/detail/237 di Akses pada tanggal 12 Desember 2017.

Muriadi Akbar. (2016). Pengaruh Komitmen Profesional, Efikasi Diri, dan Tekanan Ketaatan Terhadap Pengambilan Keputusan Etis Auditor Dengan Pertimbangan Etis Sebagai Variabel Moderating Pada Kantor Akuntan Publik Di Kota Makassar.

Ni, Luh. G. S., Nyoman, T. H., \& Ni, Kadek. S. (2014). Pengaruh Etika Profesi, Kecerdasan Intelektual, Kecerdasan Emosional, Dan Kecerdasan Spiritual Tehadap Opini Auditor. E-Journal S1 AK, Universitas Pendidikan Ganesha Jurusan Akuntansi Program S1 (Vol:2 No:1 Tahun 2014). (Studi Empiris Pada Kantor Akuntan Publik Wilayah Bali)

Suwandi. (2015) Pengaruh Self Efficacy, Kecerdasan Emosional, Tekanan Ketaatan dan Kompleksitas Tugas Terhadap Audit Judgment Auditor. Faculty of Economics Riau University, Pekanbaru, Indonesia

Tirta. H. K., Hamidah N. U., \& Ika Ruhana. (2016). Persepsi Peran Etika dan Tanggung Jawab Sosial, Sifat Machiavellian, dan Preferensi Risiko Terhadap Pengambilan Keputusan Etis. E-Journal Perpajakan, Jurusan Administrasi Bisnis, Fakultas Ilmu Administrasi Universitas Brawijaya(Vol:10 No:1 Tahun 2016)

Yeni Indra Mayeni. (2011). "Pengaruh Etika Profesi Terhadap Pengambilan Keputusan Auditor".Jurusan Akuntansi Sekolah Tinggi Ilmu Ekonomi Perbanas Surabaya

Yuliana. G. S., \& Made Yenni L. (2016). Pengaruh Kecerdasan Emosional, Kecerdasan Spiritual, Kecerdasan Intelektual, dan Independensi Terhadap Kinerja Auditor. E-Journal Akuntansi, Fakultas Ekonomi dan Bisnis Universitas Udayana(Vol:16 No:2 Tahun 2016) 